Article

\title{
Understanding the Implementation of Airbnb in Urban Contexts: Towards a Categorization of European Cities
}

\author{
Laura Serrano $^{1}\left(\mathbb{D}\right.$, Antonio Sianes ${ }^{2, *(\mathbb{D})}$ and Antonio Ariza-Montes ${ }^{1}$ (D) \\ 1 Social Matters Research Group, Universidad Loyola Andalucía, 14004 Córdoba, Spain; \\ lserrano@uloyola.es (L.S.); ariza@uloyola.es (A.A.-M.) \\ 2 Research Institute on Policies for Social Transformation, Universidad Loyola Andalucía, \\ 14004 Córdoba, Spain \\ * Correspondence: asianes@uloyola.es; Tel.: +34-957-222-220
}

Received: 15 November 2020; Accepted: 14 December 2020; Published: 16 December 2020

\begin{abstract}
The sharing economy has experienced exponential growth in recent years, especially in the short-term rentals (STRs) tourist accommodation sector. This growth has caused disruptive effects in rural and urban contexts, especially in highly touristic cities. These effects can be both positive and negative, revitalizing certain areas and bringing about tension in the socioeconomic fabric. Today, Airbnb is considered the paradigm of this sharing economy model and the STR industry leader. However, as this study suggests, on many occasions the implementation of Airbnb exhibits more of a traditional economic business model than a collaborative economic business model. Through hierarchical cluster analysis, this study identifies different groups of European cities according to the degree of professionalization of Airbnb implementation in their territory. The goal is to find similar patterns in the Airbnbisation process in major European cities, as the social, economic, and spatial impacts of various typologies are very different and even contrary. By understanding and identifying such different models implemented in each territory, better policies can be informed, and more adapted strategies can be pursued by local governments and the tourism industry.
\end{abstract}

Keywords: Airbnb; sharing economy; business model; cluster analysis; sustainable tourism; urban land use patterns

\section{Introduction}

In recent years, the sharing economy has penetrated and disrupted many economic sectors, especially in developed countries and within cities [1]. This model of the peer-to-peer economy has emerged in different economic sectors as an alternative to the global market. In particular, the short-term rental (STR) tourist accommodation sector is the sector where it has had the most disruptive effect [2]. As a result, since 2018, Airbnb has been the most powerful company in the tourist lodging sector without owning any establishments around the world [2-5].

Strong Airbnb penetration, especially in urban contexts, has caused the emergence of very important challenges due to the tensions generated in the cities where it has settled [6,7]. Some of the most important tensions are the pressure on the residential housing market [8-10], the accelerating effect in the touristification and gentrification of neighborhoods [11-14], and the conflict involved with regulatory responses [15-17]. However, these social, spatial, and economic impacts have different natures and levels of intensity depending on the degree of professionalization that the Airbnb model exhibits in each territory [8]. In the urban setting, professionalization is the process that describes the substitution of land use value for exchange value [6,18-20], which produces a conflict between 
those stakeholders who practice extractivism on the city's resources (land, heritage, labor) in the development of their business activities, and the people who inhabit the city [20].

The relevance of these effects has caused the emergence of a very robust body of academic literature. Several empirical studies have analyzed the nature of the Airbnb business model implemented in specific cities. In these studies, there is a convergence that seems to characterize two models based on the degree of professionalization that Airbnb exhibits in each specific urban context as follows: a truly collaborative model that responds to the original purpose of the sharing economy, and a commercial model that is much closer to traditional forms of the tourist accommodation sector.

Despite having universal implications, a review of the literature shows how most of the research addressing the impacts of the sharing economy adopts a micro perspective, focusing on the social and economic implications of Airbnb in very specific geographic areas [9,21-31]. Despite the existence of pioneering studies as those provided by Adamiak [17,32], Eugenio-Martín et al. [33], Gyódi [34], Heo and Blengini [35], Voltes-Dorta and Inchausti-Sintes [36], and Dogru et al. [37], the academic literature agrees on the necessity of developing more studies that use a macroeconomic aggregated perspective $[35,37]$. This article contributes to this line of research and covers a part of this gap.

In this paper, we study how Airbnb has settled in a sample of European cities to identify patterns of behavior around the different Airbnb business models. Using hierarchical cluster analysis, our study identified three groups of cities that respond to implementation in their territory of a certain Airbnb business model. Analyzing what model is implemented in each territory is crucial, as social, economic, and spatial aspects of the territory are impacted differently by each type. By understanding and detecting these different models that are implemented in each territory, better policies can be made, and more adapted strategies can be pursued by local populations and the tourism industry.

The paper is structured as follows: the next section presents a brief theoretical background for the research concerning the sharing economy, the Airbnb models, and the implications on the triple bottom line of the cities. Subsequently, methods are described in the research design section, including the approach for gathering and analyzing data. Next, the results are presented and discussed. Finally, the paper provides some concluding remarks and practical guidance as well as the limitations of this study and directions for future research.

\section{Literature Review}

\subsection{The Sharing Economy: Between a True Collaborative Economy and Platform Capitalism}

Today, the sharing economy is considered a disruptive and innovative business model [38], since it redefines traditional models and subverts the classic operational rules of economic sectors [39]. The exponential growth of this model is a response to several factors including the increase in internet accessibility [5], the development and diffusion of the use of mobile devices [40], the breakthrough in the big data analysis [41], and the loss of consumers' purchasing power after the 2008 economic crisis $[9,42,43]$.

Under the idea of an economy of free exchange between equals [44] Botsman and Rogers [45] defined the sharing economy as an economic system based on sharing underused assets or services, for free or for a fee, directly between individuals. Since its inception, the term has been extensively used in academic literature to refer to all kinds of digital platforms that allow for a connection between individuals to carry out transactions of goods and services directly with each other [43].

There is no single and generally accepted definition of the concept of the peer-to-peer market as there is no unique term to refer to this model of the economy [46]. Different definitions of the sharing economy have been enunciated from the body of academic literature using the term as a conceptual umbrella. "Sharing", "collaborative", "peer", "gig", and "platform" economies are terms that are used interchangeably [46]. For example, Rifkin [47] speaks of a "zero cost economy", Sundararajan [48] of "crowd capitalism", and Srnicek [49] of "platform capitalism". Regardless of the term, it indistinctly includes a diverse typology of digital platforms that exhibit 
different characteristics [41,43]. Airbnb, HomeAway, XiaoZhu, Uber, Deliveroo, Hapymag, BlaBlaCar, EatWith, MealSharing, RentMyWardrobe, among others are some examples of success in this type of economy.

In academia, an uncritical discourse has been built around the sharing economy, presenting it as an alternative economic model to the global market that points towards the achievement of social sustainability [50-52](activating the local economic fabric as well as the labor market of the territories), environmental sustainability (making use of existing resources), and financial sustainability (speaking of "greater efficiency" [53]). This discourse has favored the assumption that the sharing economy contributes to sustainable development [54]. However, in front of this idea, it has emerged the evidence that digital technology has become more than a simple intermediary in the sharing economy and has become a fundamental part of this with for-profit and non-profit peer exchange [55-57]. This evidence raises doubts about whether the current sharing economy shares the principles that were enunciated at its origins.

In recent years, an increasing number of authors have concluded the coexistence of two sharing economy models, which are a true "collaborative economy" model [45] versus a commercial model of "platform capitalism" [49]. The identification of two models of the sharing economy allows to differentiate one economic activity that offers a service in a regime of true collaboration between individuals, making use of underused capacities, from another economic activity that fits into an innovative business model but that responds to traditional forms of the neoliberal economy [43]. In the rest of the paper, we will refer to the former as "collaborative model" [8] and to the latter as "commercial model" [43].

Briefly delving into each of the two typologies indicated, the collaborative model is identified with non-commercial exchanges between individuals, while the commercial model is identified with neoliberal economic practices and principles that work through the digital platforms, mostly in the hands of multinationals, which, far from having a residual character in commercial transactions between firms and individuals, play an increasingly determining role [56].

The platforms of the sharing economy in the lodging sector, such as Airbnb, also participate of this tension between the two kinds of models. With the growth of tourism, academia has begun to address the issue of the lodging sector within the commercial model operating in the sharing economy and its effects on the (bio)socio-economic ecosystems of cities. In this context, tensions have already been identified between residents of neighborhoods with greater tourist pressure and users of digital platform services $[13,27,58]$.

According to Botsman and Rogers [45], the properties offered on sharing economy platforms were expected to be temporarily underused, and therefore available for the use of others. That is, temporality was a fundamental element in the early stages of the business model development. Consequently, it should not be considered a sharing economy practice to extract housing from the residential housing stock of a city to make it available in the tourist stock through a digital platform. When it occurs, the aim is not to generate an extra income that complements the income of the individual offering the good available to others. It is closer to other businesses in the traditional hosting model but developed on digital p2p platforms. The use of such platforms does not nullify how this practice is exhibiting the exact same factors as the traditional economy [24]; therefore the definition of platform capitalism [49].

Distinguishing the difference between the activity of platforms that exhibit the collaborative model and the commercial model is essential because the impacts of both business models vary considerably from one case to another. The greater the weight of the commercial model in a city is, the greater is its impact on the process of socio-spatial transformation of urban space into a tourist space at the service of a monofunctional economy hyper-dependent on the tourism sector $[59,60]$. 


\subsection{Airbnb's Impacts in the Urban Context}

Founded in 2008, Airbnb is currently the leading company in the tourist rental accommodation industry and the collaborative economy paradigm in the short-term rental tourist sector [6]. Originally, it was conceived with the idea that nonprofessional hosts would offer short-term rental accommodation in their permanent residences, connecting people "who have space to spare with those who are looking for a place to stay" [61].

Data on the company's activity show record numbers including an estimated valuation of more than 10 billion dollars, 50,000 overnight stays per day, more than 7 million homes, apartments and rooms [62], more than 500 million accumulated users, 10 million reserves, and a presence in more than 191 countries and 34,000 cities [63]. The company has experienced exponential growth in the past twelve years, driven by the professionalization of its business model [24]. Currently, different types of hosts coexist in Airbnb, differentiated by their practice of the collaborative model or the commercial model [43]. Academic literature has noticed this coexistence, and some authors make a basic division between "professionals" and "non-professionals" [64]. Other researchers choose to differentiate three categories of hosts as follow: the "capitalist" hosts, who act as professionals; the "befrienders", and the "ethitics", who acts as the non-professional hosts motivated by either question of sociability or sustainability [2]. Our analysis uses the classification of hosts proposed by Gil and Sequera [8], as it involves a deeper approach because it uses four categories and also responds to a materialistic approach to reality. In this sense, the authors first differentiate between "permanent" hosts and "sporadic" hosts as categories that exhibit an Airbnb model that does correspond to a great degree with the collaborative economy. Then, the authors also distinguish between "investor" hosts and "professional" hosts as types exhibiting an Airbnb model that is closer to the traditional economy, therefore far from the principles that govern the collaborative economy.

If Airbnb's growth in the global economy has presented record figures, its high level of penetration at the local level has resulted in very important impacts that Wegman and Jiao [6] classified as "housing market impacts" and "quality life impacts". In the first category, some of the main impacts of Airbnb are the removal of housing from the residential housing stock as the use of dwellings is transformed from residential to commercial, the rising cost of housing or the real estate investment [65]. In the second category of impacts, we find those derived from the changing of the social fabric at different levels (economic, social, special, cultural, and politician) [65] such as commercial gentrification [66], degradation of the heritage [67], compatibility by urban resources such as parking spaces [6], a saturation of public urban space, and difficult habitability of certain areas of the city [68], among others.

Previous studies at the city level, such as that by Gil and Sequera [8], or at a macro level, such as that by Adamiak [32], reveal that Airbnb follows a process of professionalization that distances it from the collaborative economy model and characterizes it as a commercial model of the traditional economy in which financial motivations prevail over the social aspects of living as a local citizen [16]. Due to the impacts resulting from this professionalization process, together with the strong growth of Airbnb in the historical centers of the most touristic cities in Europe, local government administrations have decided to tackle the problems caused by the activity of STRs. Nieuwland and van Melik [16] identified a heterogeneity of measures and policies grouped around three very different regulatory approaches in the literature, ranging from prohibition to total permissiveness. This reveals the need for a more general vision of the problem that enables public authorities to make comparative analyses between cities that suffer from the implementation of Airbnb, which would facilitate to develop and disseminate effective policies.

The theoretical framework has highlighted how the study of Airbnb has been mainly characterized from a micro perspective. The importance of our analysis relies on the necessity of scaling-up that approach, complementing the findings with a macro perspective, which opens the door for deeper and broader research on the topic. What are the different Airbnb models settling in Europe? Is it possible for cities to learn from the experiences of those that share a similar Airbnb model? Can public policies and strategies of the resilience of citizens and the local industry be shared and diffused? All these questions 
are essential to maximize the potential benefits of the implementation of Airbnb, while minimizing the undesirable impacts.

Our main approach is not only that there are substantial differences in today's Airbnb settlement in each city, but also that it is possible to find degree professionalization patterns of Airbnb models implemented in different groups of cities. The identification of these clusters of cities can be helpful not only to find models of reference on how to deal with the Airbnbisation process [8,69], but also to facilitate to the cities where Airbnb are beginning to settle could identify patterns and better guide this implantation.

Previous research has shown how the impact of Airbnb in a specific city (micro level) depends on the intensity of local penetration the platform has; therefore, our research opens the door to future lines of research where the perspective of analysis can be raised and explored patterns of the presence of the different Airbnb models at a macro level.

\section{Materials and Methods}

To answer our research questions, a hierarchical cluster analysis was performed. Cluster analysis is a statistical method to classify a given sample of subjects in a number of groups, emerging the similarities between those considered as belonging to the same group, and highlighting the differences regarding members from other groups. The objective is to sort observations into groups called clusters, so that the degree of statistical association is high among members of the same group and low between members of different groups [70]. Cluster analysis is commonly used as an exploratory technique. It does not offer unique solutions, even if a clear structure of the data exists. The solution depends on the exact method of cluster analysis, the choice of variables and the choice of the number of clusters.

We used the Inside Airbnb database, an online platform that performs web scraping of the Airbnb website and allows free access to Airbnb data. Inside Airbnb is a non-profit project launched by Murray Cox in 2016 with the aims to facilitate this data for researchers and activists who study Airbnb impacts. Inside Airbnb submits the data to a verification and analysis process prior to the publication [71]. Inside Airbnb is one of the most-used databases in Airbnb-related research [8,63,71-74]. The data used in the present study were collected between February and early March 2020, just before the lockdown was enforced in Europe because of COVID-19. At that time, the sample was composed of a set of 33 European cities for which the Inside Airbnb project collects data including Antwerp, Amsterdam, Athens, Barcelona, Berlin, Bologna, Brussels, Bordeaux, Copenhagen, Crete, Dublin, Edinburgh, Florence, Geneva, South Aegean Islands, Lisbon, London, Lyon, Madrid, Malaga, Majorca, Manchester, Milan, Munich, Naples, Porto, Paris, Prague, Rome, Seville, Valencia, Venice, and Vienna. Cluster analysis has been successfully performed with samples of similar size in many research projects [75-82]. In line with previous studies [17,42,60,83-86] the small island territories are included as they can be considered a unitary urban area in geographical, social, and economic terms [87], thus analyzed as tourist urban destinations with their own entity from a functional point of view.

Based on Gil and Sequera's [8] and Wegman and Jiao's studies [6], we selected six variables that they used to distinguish the collaborative model from the commercial model, which include: 'entire apartment', 'high availability', 'multi-listing host', 'top 20 multi-listing', 'estimated income', and 'occupancy' (see Table 1 for a better understanding). Except for the 'occupancy' variable, the others follow a directly proportional relationship. The higher the score of the variable is, the closer the Airbnb model is to the commercial model. The 'occupancy' variable works differently than the rest of the variables because it is highly determined by the geographical area and the climate in the territory. As will be explained later, the 'occupancy' variable reflects the concentration of tourism demand during a period of the year, therefore indicating the degree of the seasonality of the demand. For the purpose of our study, an additional variable was used: 'Airbnb density'. It was calculated as the number of entire apartments with high availability in each city divided by the number of conventional residential houses. The number of entire apartments with high availability was extracted from Inside Airbnb website. The number of conventional residential houses is an estimation calculated from the 
population of each city (Eurostat) and the average household size per country (UN Department of Economic and Social Affairs). This last variable presents the same proportional relationship as the former. The seven variables used in the study are briefly defined in Table 1.

Table 1. Variables.

\begin{tabular}{ll}
\hline 1. Entire apartment & $\begin{array}{l}\text { \% Entire apartments advertised by Airbnb hosts. } \\
\text { The higher the percentage of entire apartments advertised by the hosts, the closer } \\
\text { to the commercial model. }\end{array}$ \\
\hline 2. High availability & $\begin{array}{l}\text { \% Airbnb accommodations that are available more than } 60 \text { days per year. } \\
\text { The higher the percentage of listings advertised with high availability, the closer } \\
\text { to the commercial model. }\end{array}$ \\
\hline 3. Multi-listing host & $\begin{array}{l}\text { \% Airbnb hosts with more than one listing advertised. } \\
\text { The more concentration of listings per host, the closer to the commercial model. }\end{array}$ \\
\hline 4. Top 20 multi-listing host & $\begin{array}{l}\text { \% Listings accumulated by the top } 20 \text { Airbnb hosts with the most listings. } \\
\text { The higher the concentration of listings by the first } 20 \text { multi-listing host, the closer }\end{array}$ \\
\hline 5. Estimated income & $\begin{array}{l}\text { \% National GDP of the country of each city that represents the estimated average } \\
\text { profit of a year of Airbnb in that city. } \\
\text { The higher the estimated income, the closer to the commercial model. }\end{array}$ \\
\hline 6. Occupancy & $\begin{array}{l}\text { \% night stays that are booked on Airbnb. } \\
\text { 7. Airbnb density }\end{array}$ \\
\hline
\end{tabular}

Source: author's own elaboration based on data from http://insideairbnb.com/.

To gain greater knowledge of the relationships between the selected variables, an analysis of their correlation was performed. The results are shown in Figure 1. As seen, there is a considerably high correlation between 'multi-listing host' and 'high availability'. Additionally, significant correlations were detected between these two variables and the 'top 20 multi-listing host'. A remarkable correlation was found between 'estimated income' and 'Airbnb density'. Finally, smaller correlations must be taken into consideration between 'estimated income' and 'multi-listing host' and between 'Airbnb density' and 'entire apartment'. All of these findings will be very helpful when interpreting the results of the clustering.

Regarding the cluster formation method, the hierarchical conglomeration procedure and Ward's [88] method were used as the strategy of conglomeration. On the one hand, the cluster analysis is hierarchical since it is the type recommended by the literature when working with small samples [79,89]. On the other hand, as Tezanos [81] points out, there is no objective criterion to select the most appropriate method, and the selection depends, to a large extent, on the ease of interpretation of the results. Therefore, the method proposed by Ward [88] was selected, with the goal of constituting the clusters in such a way that, when two elements are grouped, the resulting loss of information is minimal. Ward's method is one of the most widely used in practice, as it presents almost all of the advantages of the mean method and is usually more discriminative in the determination of clustering levels. 


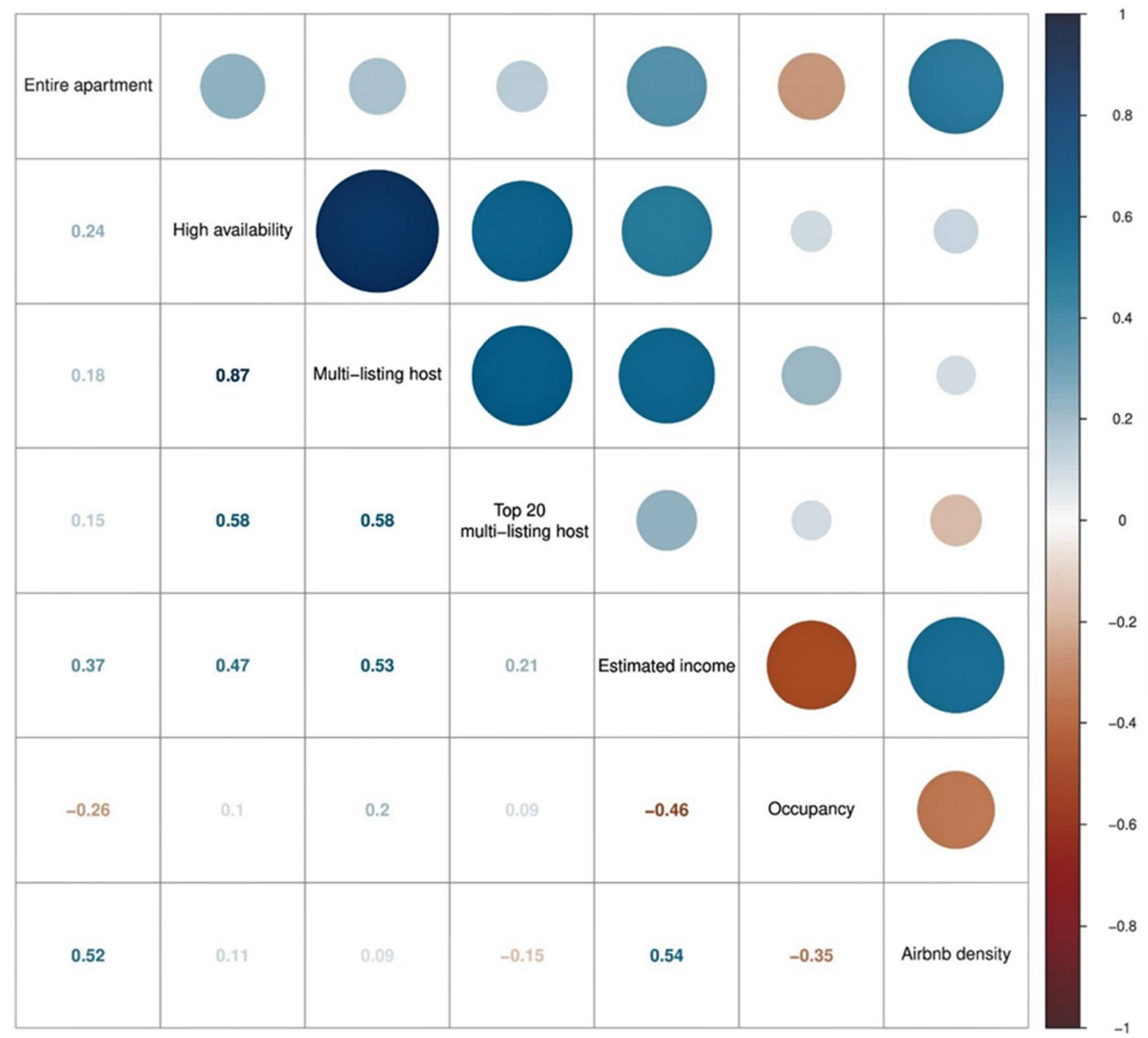

Figure 1. Results of Pearson correlation between variables. Source: author's own elaboration.

To determine when this loss of information is minimal, it is necessary to define a metric that quantifies the similarity between two observations. In this research, the Euclidean distance was chosen as the metric after standardization. The Euclidean distance is one of the most commonly used in clustering software [90-92].

Finally, the statistical analysis and presentation of the results were performed with the RStudio with NbClust, stats v3.6.2 library [93], openair [94], and ggplot2 [95] packages.

\section{Results}

\subsection{Descriptive Results}

The collected data for this study are summarized in Table 2, which shows a first set of interesting results regarding the implementation of Airbnb in each territory.

Broadly, it is noticed that the 'entire apartment' variable reaches the highest value in Majorca $(91.43 \%)$, Athens $(87.83 \%)$, and Crete $(86.96 \%)$. Compared to these territories, the lowest values are in Manchester, Berlin, and Barcelona, with $41.27 \%, 47.54 \%$, and $48.69 \%$, correspondingly. 
Table 2. Data collected for each city.

\begin{tabular}{|c|c|c|c|c|c|c|c|}
\hline City & Entire Apartment & High Availability & Multi-Listing Host & Top 20 Multi-Listing Host & Estimated Income & Occupancy & Airbnb Density \\
\hline Antwerp & $71.79 \%$ & $55.82 \%$ & $39.62 \%$ & $10.96 \%$ & $79.32 \%$ & $28.57 \%$ & $0.61 \% *$ \\
\hline Amsterdam & $78.98 \%$ & $23.60 \%$ & $21.08 \%$ & $3.69 \%$ & $116.72 \%$ & $19.78 \%$ & $4.20 \%$ \\
\hline Athens & $87.83 \%$ * & $87.44 \%$ & $50.78 \%$ & $9.04 \%$ & $130.79 \%$ & $30.22 \%$ & $2.94 \%$ \\
\hline Barcelona & $48.69 \%$ & $67.09 \%$ & $65.26 \%$ & $9.20 \%$ & $161.98 \%$ & $28.02 \%$ & $1.47 \%$ \\
\hline Berlin & $47.54 \%$ & $28.17 \%$ & $23.56 \%$ & $1.81 \%$ & $55.84 \%$ & $28.02 \%$ & $0.59 \%$ \\
\hline Bologna & $65.87 \%$ & $80.12 \%$ & $48.98 \%$ & $10.33 \%$ & $87.44 \%$ & $28.57 \%$ & $1.44 \%$ \\
\hline Brussels & $64.53 \%$ & $44.50 \%$ & $38.72 \%$ & $8.63 \%$ & $57.61 \%$ & $26.65 \%$ & $6.49 \%$ \\
\hline Bordeaux & $75.68 \%$ & $45.96 \%$ & $24.00 \%$ & $3.93 \%$ & $82.29 \%$ & $20.33 \%$ & $6.79 \%$ \\
\hline Copenhagen & $83.66 \%$ & $23.36 \%$ & $13.91 \%$ & $1.81 \%$ & $68.55 \%$ & $14.29 \%$ & $9.39 \%$ \\
\hline Crete & $86.96 \%$ & $92.56 \%$ & $67.57 \%$ & $10.83 \%$ & $228.39 \%$ & $8.52 \%$ & $5.31 \%$ \\
\hline Dublin & $49.41 \%$ & $27.19 \%$ & $43.37 \%$ & $5.43 \%$ & $65.95 \%$ & $28.02 \%$ & $0.95 \%$ \\
\hline Edinburgh & $61.46 \%$ & $51.36 \%$ & $40.41 \%$ & $5.59 \%$ & $120.32 \%$ & $29.95 \%$ & $3.14 \%$ \\
\hline Florence & $76.72 \%$ & $82.13 \%$ & $63.92 \%$ & $11.45 \%$ & $115.05 \%$ & $30.22 \%$ & $5.42 \%$ \\
\hline Geneva & $66.20 \%$ & $52.26 \%$ & $35.27 \%$ & $11.03 \%$ & $60.38 \%$ & $20.05 \%$ & $0.88 \%$ \\
\hline Sth Aegean & $80.93 \%$ & $94.75 \%$ & $72.37 \%$ & $7.61 \%$ & $476.30 \%$ & $8.52 \%$ & $12.95 \%$ \\
\hline Lisbon & $74.10 \%$ & $84.91 \%$ & $67.00 \%$ & $6.85 \%$ & $155.93 \%$ & $28.30 \%$ & $8.67 \%$ \\
\hline London & $55.46 \%$ & $41.80 \%$ & $46.65 \%$ & $4.33 \%$ & $123.63 \%$ & $23.63 \%$ & $1.09 \%$ \\
\hline Lyon & $78.29 \%$ & $34.37 \%$ & $19.88 \%$ & $3.49 \%$ & $92.81 \%$ & $14.84 \%$ & $3.96 \%$ \\
\hline Madrid & $64.72 \%$ & $58.99 \%$ & $55.30 \%$ & $7.20 \%$ & $120.18 \%$ & $30.77 \%$ & $0.92 \%$ \\
\hline Malaga & $86.21 \%$ & $84.40 \%$ & $69.56 \%$ & $20.22 \%$ & $97.97 \%$ & $28.02 \%$ & $1.94 \%$ \\
\hline Majorca & $91.43 \%$ & $90.40 \%$ & $76.88 \%$ & $23.37 \%$ & $263.88 \%$ & $10.44 \%$ & $4.10 \%$ \\
\hline Manchester & $41.27 \%$ & $83.82 \%$ & $49.13 \%$ & $22.43 \%$ & $83.89 \%$ & $28.30 \%$ & $0.16 \%$ \\
\hline Milan & $72.54 \%$ & $70.02 \%$ & $39.73 \%$ & $6.05 \%$ & $128.86 \%$ & $19.23 \%$ & $2.27 \%$ \\
\hline Munich & $55.61 \%$ & $33.28 \%$ & $20.80 \%$ & $2.42 \%$ & $90.84 \%$ & $14.29 \%$ & $0.77 \%$ \\
\hline Naples & $58.91 \%$ & $92.89 \%$ & $58.68 \%$ & $4.21 \%$ & $78.24 \%$ & $22.53 \%$ & $1.04 \%$ \\
\hline Porto & $78.06 \%$ & $87.91 \%$ & $65.69 \%$ & $7.33 \%$ & $120.34 \%$ & $31.04 \%$ & $9.44 \%$ \\
\hline Paris & $86.81 \%$ & $28.24 \%$ & $19.89 \%$ & $2.58 \%$ & $106.21 \%$ & $25.27 \%$ & $5.46 \%$ \\
\hline Prague & $78.27 \%$ & $65.78 \%$ & $64.77 \%$ & $8.35 \%$ & $156.29 \%$ & $31.04 \%$ & $1.93 \%$ \\
\hline Rome & $64.01 \%$ & $87.52 \%$ & $62.04 \%$ & $3.72 \%$ & $112.75 \%$ & $24.45 \%$ & $1.57 \%$ \\
\hline Seville & $81.38 \%$ & $81.78 \%$ & $67.68 \%$ & $12.08 \%$ & $134.55 \%$ & $35.71 \%$ & $1.75 \%$ \\
\hline Valencia & $69.61 \%$ & $83.90 \%$ & $56.38 \%$ & $10.93 \%$ & $90.14 \%$ & $26.10 \%$ & $0.49 \%$ \\
\hline Venice & $76.49 \%$ & $83.99 \%$ & $68.58 \%$ & $10.73 \%$ & $157.62 \%$ & $31.32 \%$ & $5.93 \%$ \\
\hline Vienna & $73.42 \%$ & $56.42 \%$ & $49.83 \%$ & $6.77 \%$ & $64.76 \%$ & $28.57 \%$ & $1.15 \%$ \\
\hline
\end{tabular}

* Note: highest scores are presented in bold face, lowest in italics. Source: author's own elaboration based on data from http://insideairbnb.com/. 
Once again, Crete and Majorca stand out in third and fourth place, behind Naples, among the territories with the highest values of the variable 'high availability'. The islands of the Aegean Sea are the territory with the highest value, $94.74 \%$. This availability contrasts with the values of cities such as Copenhagen, Amsterdam, Dublin, Berlin, and Paris, which do not reach $30 \%$ of the accommodation offered with $23.36 \%, 23.60 \%, 27.19 \%, 28.17 \%$, and $28.24 \%$, respectively.

The highest percentages of Airbnb hosts that have multiple listings are found in the territories of Majorca (76.88\%), the Aegean islands (72.73\%), and the city of Malaga (69.56\%), in contrast with Copenhagen, Lyon, Paris, and Munich that barely reach $20 \%$ of their hosts with multiple listings.

The cities that accumulate the most listings in the first 20 of their hosts are Majorca $(23.37 \%)$, Manchester (22.43\%), and Malaga (20.22\%), compared to cities like Berlin and Copenhagen (1.8\% both), Munich $(2.42 \%)$, and Paris $(2.58 \%)$, where the data indicate that most hosts have only one listing available on Airbnb.

The variable 'estimated income' gives very valuable information about the real value that the incomes derived from the Airbnb business represent for a host in each city or territory. The islands of the Aegean Sea stand out well above the rest of the cities $(476.30 \%)$, followed by Majorca $(263.88 \%)$ and Crete $(228.39 \%)$. Thus, this means that a host on the islands of the Aegean Sea could have an income over a year that would be four times the GDP per capita in Greece. This gives an idea of the productivity of this type of investment in these territories. The cities where we find that the 'estimated income' is lowest are Berlin (55.84\%), Brussels (57.61\%), and Geneve (60.38\%).

The values of the islands of the Aegean Sea, Crete, and Majorca once again have a remarkable behavior in the variable "occupancy", but in this case at the lowest values, with $8.52 \%$ the first two and $10.44 \%$ the third. If we put this data in relation to the fact that these three territories are islands, we observe that the information it provides is related to the seasonality of tourism, consistent with what found out by previous studies, such as Terkenli [96], Hof and Blázquez-Salom [58], Andolina et al. [97], or Saéz-Fernández et al. [98]. They are territories that visitors who use Airbnb receive for a very specific time. Faced with these territories with low annual occupancy, we find destinations such as Seville, Venice, Porto, Prague, Madrid, Athens, and Florence that exceed 30\% annual occupancy, are cities that receive visitors in a much more homogeneous way along the whole the year.

Finally, the highest values of the 'Airbnb density' variable are found in the Aegean islands with 12.95\%, Copenhagen with 9.39\%, Porto with 9.44\%, and Lisbon with $8.67 \%$. On the other side of the spectrum, cities such as Antwerp, Berlin, Dublin, Geneva, Madrid, Manchester, Munich, and Valencia have less than $1 \%$ of their housing removed from the residential housing stock Airbnb activities.

\subsection{Dendrogram}

The 33 European cities were grouped by performing a hierarchical cluster analysis of the seven variables identified. As explained in the methodology section, to determine the optimal number of clusters, the $\mathrm{R}$ package NbClust [93] was applied to determine the best number of clusters using 30 different methods. As seen in Figure 2, most of the methods suggest that the optimal number of clusters is three.

The resulting dendrogram after calculation of the cluster analysis using Ward's method and the Euclidean distance is presented in Figure 3.

The dendrogram graphically depicts the distances between cities found in each cluster. Horizontal lines show the cities joined according to the number of clusters taken each time. The analysis of the resulting dendrogram suggests the consideration of three clusters (colored in red, blue, and green). Table 3 summarizes the clusters found, composed as follows: 
Table 3. Cluster membership.

\begin{tabular}{cc}
\hline Cluster 1 & $\begin{array}{c}\text { Amsterdam, Antwerp, Berlin, Brussels, Bordeaux, Copenhagen, Dublin, } \\
\text { Edinburgh, London, Lyon, Madrid, Geneva, Milan, Munich, Paris, Vienna }\end{array}$ \\
\hline Cluster 2 & $\begin{array}{c}\text { Athens, Barcelona, Bologna, Florence, Lisbon, Malaga, Manchester, Naples, } \\
\text { Port, Prague, Rome, Seville, Valencia, Venice }\end{array}$ \\
\hline Cluster 3 & South Aegean Island, Crete, Majorca \\
\hline & Source: author's own elaboration.
\end{tabular}

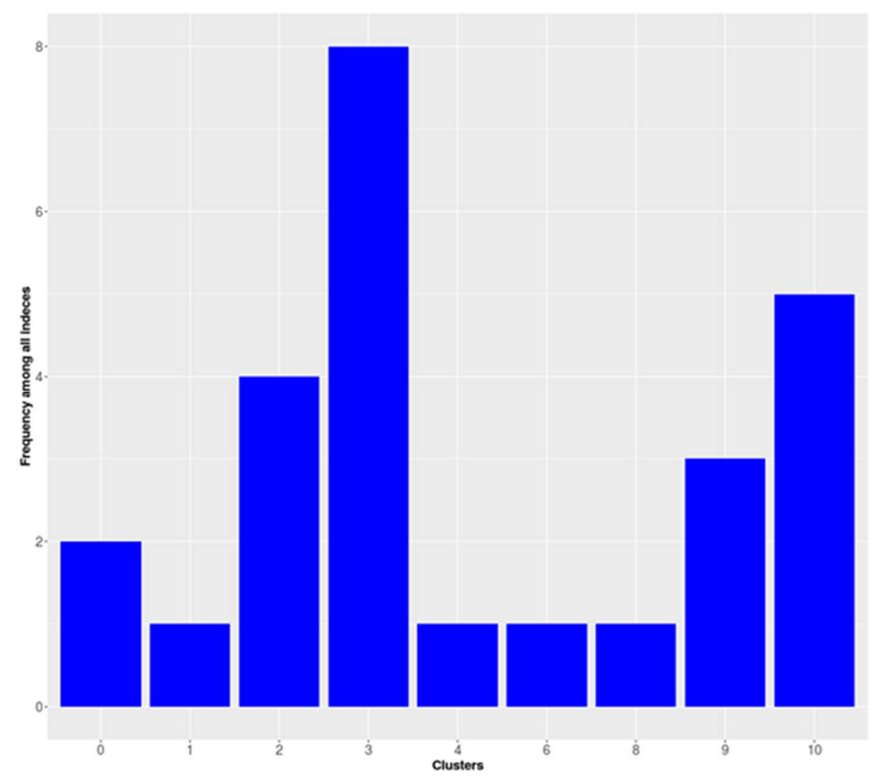

Figure 2. Optimal number of clusters. Source: author's own elaboration.

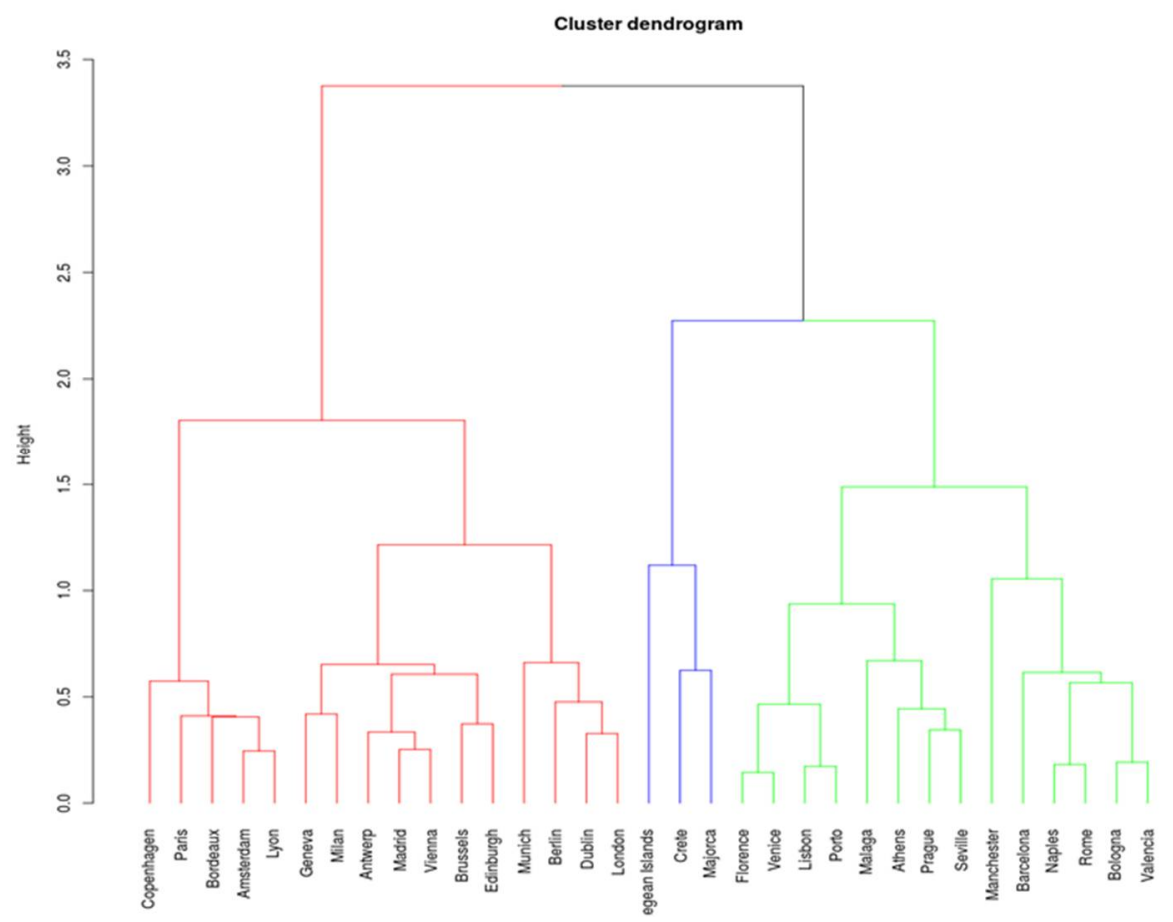

Figure 3. Dendrogram Ward's method and Euclidean distance. Source: author's own elaboration. 
The information that is most initially obvious from the dendrogram is the balance or imbalance in the composition of each of the clusters. In this case, we find that cluster 1 and cluster 2 are very balanced, in contrast to the third cluster, which is only made up of the three territories of Majorca, the South Aegean Islands, and Crete. Without having yet analyzed the behavior of the different variables, we can say that the third cluster has begun to clearly differentiate itself from the other two.

Once the composition of each cluster has been determined, the next step was to delve into the variables.

\subsection{ANOVA and Boxplot Analysis}

The last stage of the cluster analysis was the validation of the test results. ANOVA is a test applicable when comparing three or more groups together, to see if there are significant differences among them, and in what dimensions or variables these differences occur. To test the hypothesis that there are differences statistically significant between the variables, a one-way ANOVA test (95\% confidence level) was performed, with the independent variable or factor being the variable city, and the seven variables included in the analysis being the dependent variables. Table 4 shows the results.

Table 4. One-way ANOVA.

\begin{tabular}{cccc}
\hline Variable & Sum Sq. & F & Pr $(>\mathbf{F})$ \\
\hline Entire apartment & 1.57 & 3.954 & $5.60 \times 10^{-2}$ \\
High availability & 10.03 & 80.82 & $3.82 \times 10^{-10 *}$ \\
Multi-listing host & 9.29 & 62.94 & $5.89 \times 10^{-9} *$ \\
Top 20 multi-listing host & 4.43 & 14.57 & $6.06 \times 10^{-4 *}$ \\
Estimated income & 6.68 & 28.8 & $7.5 \times 10^{-6} *$ \\
Occupancy & 0.48 & 1.13 & $2.96 \times 10^{-1}$ \\
Airbnb density & 1.11 & 2.69 & $1.11 \times 10^{-1}$ \\
* Statistically significant difference at 95\% confidence level, $\alpha>0.05$. Source: author's own elaboration.
\end{tabular}

The ANOVA reveals significant differences in the variables 'high availability', 'multi-listing host', 'top20 multi-listing host' and 'estimated income', with a level of significance much less than our chosen statistical level accepted as significant $\alpha>0.01$.

We can expand these results with a graphical representation that depicts the significance of the differences between each variable in each of the three groups. To do so, Figure 4 shows the boxplots made with the mean (centroid) for each of the seven variables by cluster, showing which differences are significant. To calculate the centroids, we normalized each variable from 0 to 1 , and the resulting numeric information for each centroid is provided in Table 5.

The boxplots confirm that there are significant differences between the clusters; therefore, the Airbnb business model exhibited in the cities belonging to each cluster is significantly different. The boxplot also shows some outliers that may be interesting to explore individually, as will be suggested for future lines of research.

Once the clusters have been identified, it is now convenient to look at their characterization as a representative of each Airbnb business model, highlighting their similarities and differences. To do this, in a first approximation, all the variables that present significant differences will be used between the clusters. 

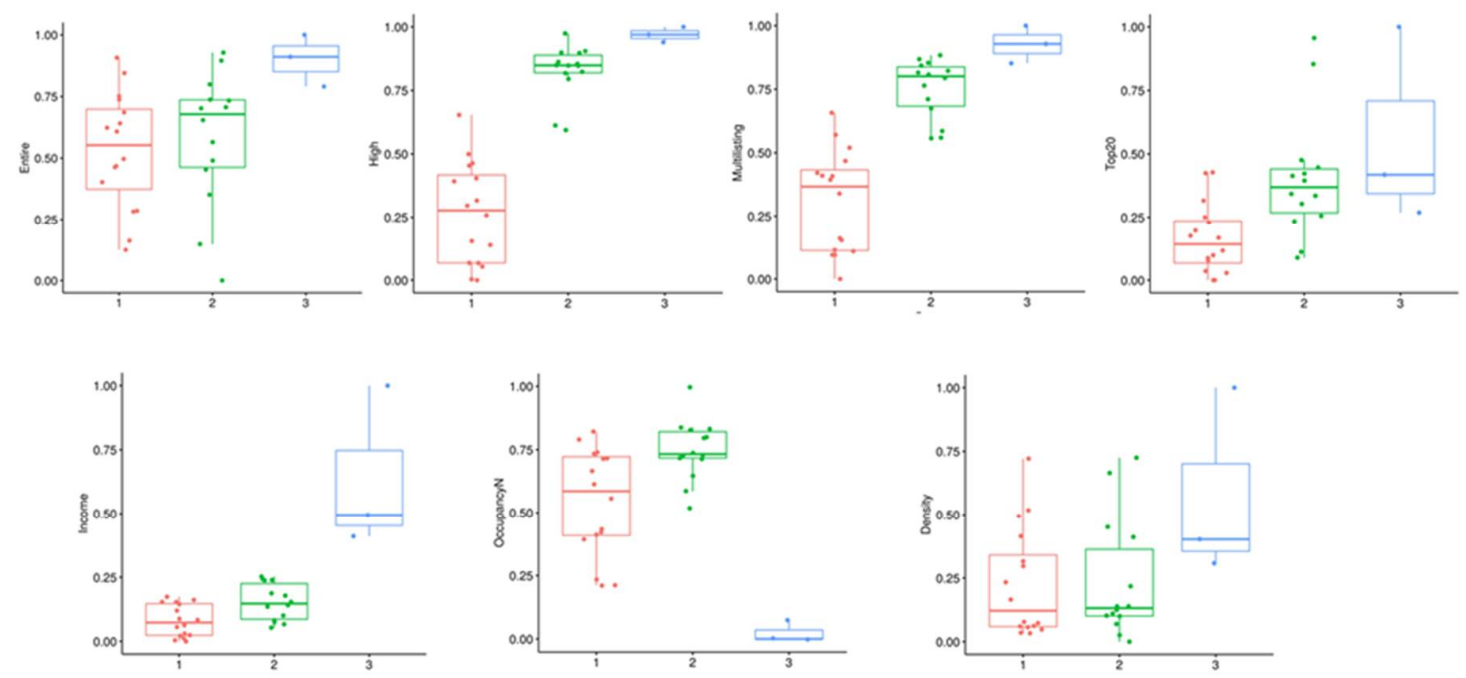

- Cluster 1 - Cluster 2 - Cluster 3

Figure 4. ANOVA boxplots variables for each cluster. Source: author's own elaboration.

Table 5. Means (centroid) of each variable by cluster.

\begin{tabular}{lccccccc}
\hline & Entire Apartment & High Availability & Multi-Listing Host & $\begin{array}{c}\text { Top20 Multi- } \\
\text { Listing Host }\end{array}$ & Estimated Income & Occupancy & Airbnb Density \\
\hline Cluster 1 & 0.55 & 0.27 & 0.36 & 0.36 & 0.07 & 0.58 \\
Cluster 2 & 0.67 & 0.84 & 0.80 & 0.80 & 0.14 & 0.12 \\
Cluster 3 & 0.91 & 0.96 & 0.92 & 0.92 & 0.49 & 0.02 & 0.40 \\
\hline
\end{tabular}

Source: author's own elaboration.

On the one hand, we observed that in almost all the variables, cluster 3 falls behind cluster 1 , and there is a large difference; however, the distance from cluster 2 is narrower, even remarkably closer in certain variables. In all variables, cluster 3 shows a marked direction towards the highest levels, a sign of the highest degree of Airbnb professionalization. A notable exception is the variable 'occupancy', whose direction is the inverse. As we pointed out in the methodology section, the variable occupancy rate provides information about the intensity of the seasonal component of tourism in these territories. Therefore, the insular characteristics of these territories might have an impact on the configuration of their Airbnb models.

On the other hand, we observed how cluster 1 is the most distant and differentiated from cluster 3 , but shares some inertia and even exact values with cluster 2 in certain variables, such as 'Airbnb density', 'estimated income', or 'occupancy'. The variables that justify separating both clusters are thus 'entire apartment', 'high availability', 'multi-listing hosts', and 'top20', in line with what is suggested by authors as Gil and Sequera [8] and Wegmann and Jiao [6]. Therefore, in the cities comprised in cluster 1, the Airbnb model that is implemented has a lower degree of professionalization than the Airbnb model shared by the cities of cluster 2, and much less than those of cluster 3 .

In the subsequent section we discuss all the results obtained through a relational analysis between the information provided by the behavior of the variables on the Airbnb models that is implemented in the cities of each cluster and the evidence that has already been studied in the literature.

\section{Discussion}

The objective of our research was to explore the degree of professionalization of the Airbnb model implemented in a series of 33 European cities, to identify the existence of patterns towards a more collaborative model or to a commercial one. As pointed out, this differentiation is crucial as the different stakeholders of a city could benefit from a deeper analysis of a phenomenon such as Airbnb, which is especially disruptive in the configuration of urban space and in the land use. 
Using the seven variables and our previous analyses as a reference, we delved into the analysis of the three clusters, by putting them in a variable-by-variable relationship with the two models previously discussed in the literature. For this, we used the graphical representation of the profiles of the three clusters (see Figure 5), which was ultimately derived from the profiles of the cities that were grouped based on these variables.

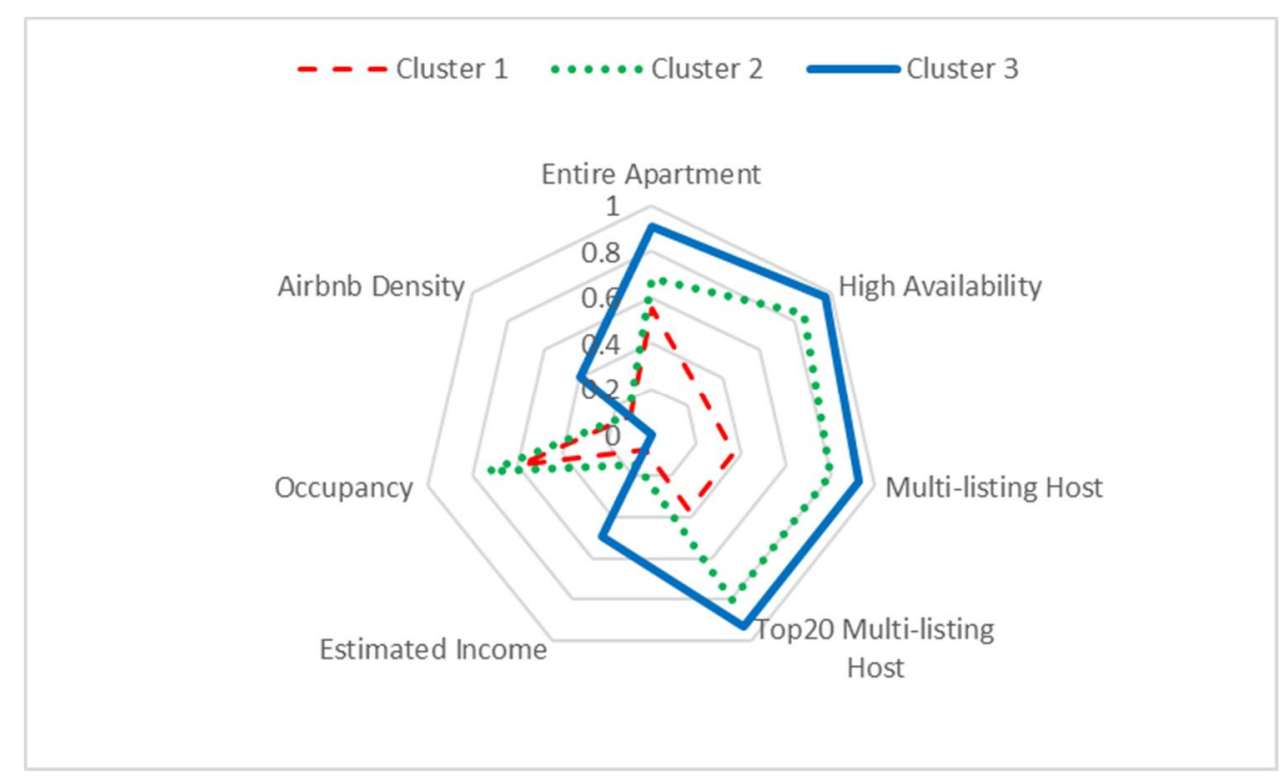

Figure 5. Profiles of the three clusters. Source: author's own elaboration.

The values are ordered so that the closer to 1 the value of the variable is, the greater the degree of professionalization the Airbnb model exhibit that is described by that variable, and thus the closest to what we called the commercial model.

Considering the composition of cluster 3, we determined that it is a cluster composed of three territories, not cities, which have particularity in common. They are islands and this geographical particularity that might determine the behavior of its variables and the relationship with the Airbnb model that is implemented in them. We will call this cluster 3 the island territories.

"The island territories" are territories marked by their insular character. This geographical characteristic determines the relationship of these three territories with the rest of the world at all levels. The insular character is a subject that has been extensively studied in all fields, including urban studies, tourism, economic, and anthropological. However, although the insularity component is decisive in the dynamics of these territories, factors such as seasonality among others mark the Airbnb implementation pattern in them. All the variables tend to have a value very close to 1 , except for the variable 'occupancy', which is explained by the insular nature of the territories that make up the cluster. The islands are eminently tourist destinations with high seasonality which translates to a very low occupancy rate, since occupancy tends to be concentrated during a few months and remains at very low levels during the rest of the year. This would explain the behavior of the 'occupancy' variable.

Considering the behavior of the variables, the Airbnb model that is evident in the territories that make up the cluster is a commercial model, which exhibits the functions of the traditional economy, and is a result of the fact that these are highly touristified territories $[28,33,58,99]$. The highest concentration of listings is found in island settlements.

We analyzed the composition of cluster 1 and cluster 2, and we found the first differentiating characteristics between the two. Although the composition of the two clusters is balanced, a deeper analysis showed information that corresponds to existing Airbnb literature. On the one hand, cluster 2 includes all cities in Southern European countries, with certain notable exceptions in Madrid and Milan. Therefore, the cities of Spain, Italy, Portugal, and Greece are in this group, along with two cities 
that break with these characteristics: Prague and Manchester. Before considering the latter to be an outlier, its characteristics and its socio-economic and spatial context need to be studied in greater depth to draw conclusions. The other city, Prague, although it does not belong in the southern European countries, does share two very powerful features with the rest of the cities. They are all eminently tourist cities, have a strong tourist component in their economies, and respond to an economic context that is not as developed as the cities in the other clusters. We will call cluster 2 "Europe's playground".

This label reflects properly two facts that characterize this cluster. On the one hand, "Europe's playground" is integrated by a set of destinations characterized by a very high degree of touristification, as well as the destinations of cluster 3. These destinations are in the European countries that suffer the highest tourist pressure data from the statistical office of the European Union (Eurostat) for 2018. Eurostat, in its data series calledTourism intensity, places Greece (11 night stays per inhabitant), Spain (10), Portugal (7.6) and Italy (7.1) among the top 10 destinations with the highest degree of tourist intensity. On the other hand, these destinations are in the European countries that are the most frequented destinations by the residents of European Union member countries. The Eurostat data series on Destinations for outbound trips made by EU residents within the EU, in terms of nights spent, establish that Spain, Italy, Greece, and Portugal account for $47.5 \%$ of these overnight stays.

According to the values of the variables, we can say that they are not as close to 1 as the Airbnb model corresponding to cluster 3, but they remain high values, especially those variables that most strongly characterize the Airbnb business model. We understand that this is a trend towards the Airbnbisation of these cities, which in the current context of COVID-19 has slowed down. The Airbnb model of the cities in this cluster would therefore also have a high level and, above all, a tendency towards professionalization $[8,18,59,69,100-102]$.

This is compatible with the idea, pointed out by many authors, that the degree of touristification is directly related to the uneven development of capitalism $[18,59,100]$. The structure of the regional economy responds to an institutional design through the policies the specialization of the economy of these territories in sectors with little added value as activities as tourism and hospitality, labor-intensive sectors.

In cluster 1, however, we find a series of cities that, although some have a strong tourist component, are large capitals whose economy is much more industrialized and financialized than the cities in cluster 2. We refer, for example, to Paris, London, and Amsterdam. This explains why Madrid and Milan also belong to this cluster. All these cities are highly touristic cities but have a strong business component in their economies. The rest are medium-sized cities that share the characteristic of being productive and economic centers due to their capital statuses, such as Dublin, Vienna, Copenhagen, Berlin, and Brussels, or industrial production centers such as Antwerp, Bordeaux, and Lyon. In short, they are defined as opposed to the cities of cluster 2 as cities whose economies are not monopolized by the tourism sector. We will call this cluster: "the production center of Europe".

"The production center of Europe", with values of the variables closest to zero, shows a degree of professionalization of the Airbnb model that is much lower than that observed in the cities of the other two clusters. The values are drastically reduced in the variables 'high availability, 'multi-listing', 'top20' and 'entire apartment', but especially in the first two. These tell us about the type of host that is mostly found in these cities: people who host using a resource that is wasted in their own home, therefore responding to a collaborative model that is close to the original idea of the sharing economy [8]. As we have pointed out, these are cities where the touristification process is slower for different reasons, but where the Airbnbisation-touristification binomial is not accelerating as in cluster 2.

The research results are consistent with the data on tourist flows from the European Statistical Office (Eurostat). Eurostat provides several data series on regional patterns of tourism in the European Union that allow us to draw a geographical map of tourism and that reinforces the profile of the distribution resulting from the cluster analysis. 
Thus, we find three well-differentiated clusters with a very specific geographical distribution of the cities that compose them and in which, in view of the analysis of the behavior of the variables, the Airbnb model is implemented with different degrees of professionalization.

Cities included in cluster 1, "the production center of Europe", show a lower degree of professionalization than compared to the rest of the European cities. The cities belonging to this cluster show characteristics of what we called the collaborative model. This could clash with evidence that there are cities that receive large tourist flows in cluster 1, such as Madrid, Paris, London, and Amsterdam. Indeed, they are cities in which Airbnb is widely established and also suffer its impacts, as studied in this way in the literature [32]. However, their productive economic fabric is strong and extensive enough (note that they are capital of states) so that the tourist flows they receive are not those that dominate their economy.

At a different point, we find cluster 2, almost entirely integrated by cities of Southern European countries. The values of the variables of cluster 2 reveal a strong degree of professionalization of the Airbnb model, showing a clear tendency towards what we defined as the commercial model. There is a high dependence of tourist activities in these cities, and the settlement of Airbnb is only exacerbating this touristification process.

Finally, if we clearly see in cluster 2 a tendency towards the commercial nature of the Airbnb model, the behavior of the variables in cluster 3 continues an upward direction on the degree of professionalization. Composed of island territories, compared to the two other clusters, which were made up of cities, the analysis of the variables concludes that the Airbnb model that absolutely predominates in these territories of cluster 3 is the commercial model, already very far from a true collaborative economy model.

This analysis provides important guidance for local public policymakers and the local traditional lodging sector. The heterogeneity of measures with which city policymakers try to mitigate the negative impacts of Airbnb's invasion of some areas leads to the conclusion that many cities do not understand how to control this newcomer in the urban tourism field $[6,7,15,16,20,103]$. Our findings provide support presented in this series of clusters of cities sharing the Airbnb model established in their territory, which allows decision-makers to identify cities in the same situation. It opens the door to focus on the study of the measures developed in them and the difficulties found by local administrations when implementing them, thus facilitating the diffusion of successful local public policies.

In summary, this analysis of the different business models implemented in each territory concludes that, in most European urban contexts, Airbnb has led to an activity that is far from the characterizing principles of the sharing economy. Instead, it approaches to commercial models of the traditional economy that offer services similar to the conventional hospitality industry but use a digital platform as a distribution channel. These findings at the macro level are in tune with the conclusions established by other academic research when analyzing specific cities such as Madrid [8,24], Lisbon [9,69] Barcelona [104,105], Seville [66,106], or London [55,107], cities that bear great tourist pressure and where the negative impacts on social, economic, and environmental sustainability are evidenced.

However, the results obtained from the cluster analysis have allowed to better understand the relationships between seven selected variables and the type of Airbnb model implemented in the context of European cities. By analyzing the set of variables in each cluster in a comparative way, we provide news on those that usually characterize each model by comparing these territories to others where the collaborative economy model is the dominant one.

\section{Limitations and Future Lines of Research}

It is important to note that the conclusions drawn from this analysis are made from the perspective of the exploratory nature of the study. That is, without attributing confirmatory properties to the results by attributing statistical significance. Additionally, although the current study makes an interesting and significant contribution, some limitations should be noted. 
First, as a general limitation in research addressing local levels, we would like to point out that one of the major limitations that we found when performing the analysis was the question of finding ordered and accessible data to build the database. Local administrations do not dedicate enough resources to the systematic collection of data related to the accommodation offerings of platforms such as Airbnb in general, the statistics at the municipal level are very poor and not well systematized, and their development depends on the political will of the government team at a given moment. This results in little data, no time series, and a very heterogeneous nature of data being available to researchers, which makes serious and in-depth studies about Airbnb and its impacts in urban contexts difficult. Second, the sample of the study was limited by the database used, the Inside Airbnb website, which does not have data for all the cities where Airbnb is established. Third, the study is limited to the urban context, and perhaps it would be interesting to explore the behavior of Airbnb in rural contexts or in very specific contexts such as coastal areas that suffer great tourist pressure but are not made up of large permanent population centers. Finally, the study is limited to a very specific territorial area: Western Europe.

Based on the findings of the present article, it would be interesting to point out several lines of research for future studies. The research analysis is valid and sufficient for the objective that we set as research question set for this study, but it opens up a truly really interesting line of research, which is to continue deepening knowledge about the factors that determine which sharing economy model is implemented in urban territories in a market such as short-term rental tourist accommodation, and what its relationship with urban land use and the impacts of the triple bottom line are. We are therefore committed to refining the analysis to further investigate the results.

Broader generalization of the results may also be possible by expanding the territorial focus. On the one hand, including new European territories to future analysis. Inside Airbnb is a living database that periodically incorporates data on new cities and territories, and today there are new urban destinations available to those included when data was collected (March 2020). On the other hand, and continuing in the line of expanding the sample size, we believe that it would be very interesting to replicate the study without limiting the chosen cities to the European continent, but expanding the database of global cities whose records can be found on Inside Airbnb. Broadening the dataset represents an opportunity for future lines of research to continue deepening into the configuration of clusters, for example excluding island territories as those gathered in cluster 3 , to study if changes the clusters and how. All these future lines will add depth and heterogeneity to the results achieved in this study.

It would be highly recommended to use services such as AirDNA, which would give access to data from a greater number of cities on five continents. These elements would introduce a macroeconomic perspective that is very interesting and could continue to be deepened. Although, as we previously pointed out, even though there are some studies $[35,37]$ that explore the relationship between macroeconomic factors and the presence of Airbnb in different territories, most of the academic literature addresses Airbnb from a micro perspective. Therefore, it would be of great interest for future studies to consider exploring the classification of the cluster analysis based on the endogenous variables used in this analysis and linked with each Airbnb business model, with significant macroeconomic variables, and exogenous variables linked with the socioeconomic environment of each country. This is important to deepen the understanding about the macro-micro relationship in the implementation of the Airbnb model on a global level land use.

Author Contributions: Conceptualization, L.S. and A.S.; methodology, L.S. and A.S.; software, L.S.; validation, A.S. and A.A.-M.; formal analysis, L.S., A.S., and A.A.-M.; investigation, L.S.; resources, L.S.; data curation, A.A.-M.; writing-original draft preparation, L.S.; writing-review and editing, L.S., A.S., and A.A.-M.; visualization, L.S.; supervision, A.A.-M. and A.S.; All authors have read and agreed to the published version of the manuscript.

Funding: This research received no external funding.

Conflicts of Interest: The authors declare no conflict of interest. 


\section{References}

1. Belarmino, A.; Koh, Y. A critical review of research regarding peer-to-peer accommodations. Int. J. Hosp. Manag. 2020, 84, 102315. [CrossRef]

2. Dolnicar, S.; Zare, S. COVID19 and Airbnb—Disrupting the disruptor. Ann. Tour. Res. 2020, 83, 102961. [CrossRef]

3. Petruzzi, M.A.; Sheppard, V.; Marques, C. Positioning Airbnb and Fairbnb in the sharing-exchange continuum. Curr. Issues Tour. 2019, 1-4. [CrossRef]

4. Sthapit, E.; Jiménez-Barreto, J. You never know what you will get in an Airbnb: Poor communication destroys value for guests. Curr. Issues Tour. 2018, 22, 2315-2318. [CrossRef]

5. Sigala, M. New technologies in tourism: From multi-disciplinary to anti-disciplinary advances and trajectories. Tour. Manag. Perspect. 2018, 25, 151-155. [CrossRef]

6. Wegmann, J.; Jiao, J. Taming Airbnb: Toward guiding principles for local regulation of urban vacation rentals based on empirical results from five US cities. Land Use Policy 2017, 69, 494-501. [CrossRef]

7. DiNatale, S.; Lewis, R.; Parker, R. Short-term rentals in small cities in Oregon: Impacts and regulations. Land Use Policy 2018, 79, 407-423. [CrossRef]

8. Gil, J.; Sequera, J. The professionalization of Airbnb in Madrid: Far from a collaborative economy. Curr. Issues Tour. 2020, 1-20. [CrossRef]

9. Cocola-Gant, A.; Gago, A. Airbnb, buy-to-let investment and tourism-driven displacement: A case study in Lisbon. Environ. Plan. A Econ. Space 2019, 1-18. [CrossRef]

10. Garcia-López, M.-À.; Jofre-Monseny, J.; Martínez Mazza, R.; Segú, M. Do Short-Term Rental Platforms Affect Housing Markets? Evidence From Airbnb in Barcelona. J. Urban Econ. 2020, 119, 103278. [CrossRef]

11. Escobedo, D.N. Foreigners as gentrifiers and tourists in a Mexican historic district. Urban Stud. 2020, 57, 3151-3168. [CrossRef]

12. Wachsmuth, D.; Weisler, A. Airbnb and the rent gap: Gentrification through the sharing economy. Environ. Plan. A Econ. Space 2018, 50, 1147-1170. [CrossRef]

13. Ioannides, D.; Röslmaier, M.; van der Zee, E. Airbnb as an instigator of 'tourism bubble' expansion in Utrecht's Lombok neighbourhood. Tour. Geogr. 2018, 21, 822-840. [CrossRef]

14. Lane, B. Will sustainable tourism research be sustainable in the future? An opinion piece. Tour. Manag. Perspect. 2018, 25, 161-164. [CrossRef]

15. Cassell, M.K.; Deutsch, A.M. Urban Challenges and the Gig Economy: How German Cities Cope with the Rise of Airbnb. Ger. Politics 2020, 1-22. [CrossRef]

16. Nieuwland, S.; Van Melik, R. Regulating Airbnb: How cities deal with perceived negative externalities of short-term rentals. Curr. Issues Tour. 2020, 23, 811-825. [CrossRef]

17. Adamiak, C. Mapping Airbnb supply in European cities. Ann. Tour. Res. 2018, 71, 67-71. [CrossRef]

18. Mansilla, J. Gentrificación, Turistificación y Clases Sociales en las Ciudades del Mediterráneo; El Turismo en la Geopolítica del Mediterráneo Alba Sud Editorial: Barcelona, Spain, 2019; Volume 9, pp. 62-65.

19. Harvey, D. The Right to City. New Left Rev. 2008, 53, 23-40.

20. Cao, Y.; Liu, R.; Qi, W.; Wen, J. Urban Land Regulation and Heterogeneity of Housing Conditions of Inter-Provincial Migrants in China. Land 2020, 9, 428. [CrossRef]

21. Boros, L.; Dudas, G.; Kovalcsik, T.; Papp, S.; Vida, G. Airbnb in Budapest: Analysing Spatial Patterns and Room Rates of Hotels and Peer-To-Peer Accommodations. Geoj. Tour. Geosites 2018, 10, $26-38$.

22. Celata, F.; Romano, A. Overtourism and online short-term rental platforms in Italian cities. J. Sustain. Tour. 2020, 1-20. [CrossRef]

23. Chica-Olmo, J.; González-Morales, J.G.; Zafra-Gómez, J.L. Effects of location on Airbnb apartment pricing in Málaga. Tour. Manag. 2020, 77, 103981. [CrossRef]

24. Gil, J.; Sequera, J. Expansión de la ciudad turística y nuevas resistencias. El caso de Airbnb en Madrid. Rev. Metodol. Cienc. Soc. 2018, 41, 15-32. [CrossRef]

25. Gunter, U.; Önder, I. Determinants of Airbnb demand in Vienna and their implications for the traditional accommodation industry. Tour. Econ. 2017, 24, 270-293. [CrossRef]

26. Jiao, J.; Bai, S. Cities reshaped by Airbnb: A case study in New York City, Chicago, and Los Angeles. Environ. Plan. A Econ. Space 2019, 52, 10-13. [CrossRef] 
27. Ki, D.; Lee, S. Spatial Distribution and Location Characteristics of Airbnb in Seoul, Korea. Sustainability 2019, 11, 4108. [CrossRef]

28. Malazizi, N.; Alipour, H.; Olya, H.G.T. Risk Perceptions of Airbnb Hosts: Evidence from a Mediterranean Island. Sustainability 2018, 10, 1349. [CrossRef]

29. Salvia, G.; Morello, E. Sharing cities and citizens sharing: Perceptions and practices in Milan. Cities 2020, 98, 102592. [CrossRef]

30. Xie, K.L.; Kwok, L.; Heo, C.Y. Are Neighbors Friends or Foes? Assessing Airbnb Listings' Agglomeration Effect in New York City. Cornell Hosp. Q. 2020, 61, 128-141. [CrossRef]

31. Zhang, Z.; Fu, R.J. Assessing Airbnb Logistics in Cities: Geographic Information System and Convenience Theory. Sustainability 2019, 11, 2462. [CrossRef]

32. Adamiak, C. Current state and development of Airbnb accommodation offer in 167 countries. Curr. Issues Tour. 2019, 1-19. [CrossRef]

33. Eugenio-Martin, J.L.; Cazorla-Artiles, J.M.; González-Martel, C. On the determinants of Airbnb location and its spatial distribution. Tour. Econ. 2019, 25, 1224-1244. [CrossRef]

34. Gyódi, K. Airbnb in European cities: Business as usual or true sharing economy? J. Clean. Prod. 2019, 221, 536-551. [CrossRef]

35. Heo, C.Y.; Blengini, I. A macroeconomic perspective on Airbnb's global presence. Int. J. Hosp. Manag. 2019, 78, 47-49. [CrossRef]

36. Voltes-Dorta, A.; Inchausti-Sintes, F. The spatial and quality dimensions of Airbnb markets. Tour. Econ. 2020, 1-15. [CrossRef]

37. Dogru, T.; Zhang, Y.; Suessc, C.; Modyd, M.; Bulute, U.; Sirakaya-Turkf, E. What caused the rise of Airbnb? An examination of key macroeconomic factors. Tour. Manag. 2020, 81, 104134. [CrossRef]

38. Toni, M.; Renzi, M.F.; Mattia, G. Understanding the link between collaborative economy and sustainable behaviour: An empirical investigation. J. Clean. Prod. 2018, 172, 4467-4477. [CrossRef]

39. Serrano, L.; Ariza-Montes, A.; Nader, M.; Sianes, A.; Law, R. Exploring preferences and sustainable attitudes of Airbnb green users in the review comments and ratings: A text mining approach. J. Sustain. Tour. 2020, 1-19. [CrossRef]

40. Dredge, D.; Gyimóthy, S. Collaborative Economy and Tourism. In Collaborative Economy and Tourism: Perspectives, Politics, Policies and Prospects; Dredge, D., Gyimóthy, S., Eds.; Springer: New York, NY, USA, 2017; Volume 6, pp. 1-12. [CrossRef]

41. Wirtz, J.; So, K.K.F.; Mody, M.A.; Liu, S.Q.; Chun, H.H. Platforms in the peer-to-peer sharing economy. J. Serv. Manag. 2019, 30, 452-483. [CrossRef]

42. Adamiak, C.; Szyda, B.; Dubownik, A.; García-Álvarez, D. Airbnb Offer in Spain-Spatial Analysis of the Pattern and Determinants of Its Distribution. ISPRS Int. J. Geo-Inf. 2019, 8, 155. [CrossRef]

43. Gil, J. Cambios en la producción y el consumo del turismo. El caso de Airbnb. In Turistifación Global Perspectivas Críticas en Turismo; Cañada, E., Murray, I., Eds.; Icaria: Barcelona, Spain, 2019; pp. 325-342.

44. Morell, M. Turismo y diferencial de renta. No hay vacaciones para la lucha de clase. In Turistificación Global Perspectivas Críticas en Turismo; Cañada, E., Murray, I., Eds.; Icaria: Barcelona, Spain, 2019; pp. 309-323.

45. Botsman, R.; Rogers, R. What's Mine Is Yours: The Rise of Collaborative Consumption; Harper Collins: New York, NY, USA, 2010; 304p.

46. Calo, R.; Rosenblat, A. The taking economy: Uber, Information, and Power. Columbia Law Rev. 2017, 117, 1623-1690. [CrossRef]

47. Rifkin, J. The Zero Marginal Cost Society: The Internet of Things, the Collaborative Commons, and the Eclipse of Capitalism; Palgrave Macmillan: New York, NY, USA; St. Martin’s Publishing Group: New York, NY, USA, 2014; ISBN 9781137437761.

48. Sundararajan, A. The Sharing Economy: The End of Employment and the Rise of Crowd-Based Capitalism; MIT Press: Cambridge, MA, USA, 2016; 256p.

49. Srnicek, N. Platform Capitalism; Polity Press: Cambridge, UK, 2017; 120p.

50. Leoni, G.; Parker, L.D. Governance and control of sharing economy platforms: Hosting on Airbnb. Br. Account. Rev. 2019, 51, 100814. [CrossRef]

51. Dredge, D.; Gyimóthy, S. The collaborative economy and tourism: Critical perspectives, questionable claims and silenced voices. Tour. Recreat. Res. 2015, 40, 286-302. [CrossRef] 
52. Böcker, L.; Meelen, T. Sharing for people, planet or profit? Analysing motivations for intended sharing economy participation. Environ. Innov. Soc. Transit. 2017, 23, 28-39. [CrossRef]

53. Palgan, Y.V.; Zvolska, L.; Mont, O. Sustainability framings of accommodation sharing. Environ. Innov. Soc. Transit. 2017, 23, 70-83. [CrossRef]

54. Gössling, S.; Scott, D.; Hall, C.M. Pandemics, tourism and global change: A rapid assessment of COVID-19. J. Sustain. Tour. 2020, 29, 1-20. [CrossRef]

55. Ferreri, M.; Sanyal, R. Platform economies and urban planning: Airbnb and regulated deregulation in London. Urban Stud. 2018, 55, 3353-3368. [CrossRef]

56. Gössling, S.; Hall, C.M. Sharing versus collaborative economy: How to align ICT developments and the SDGs in tourism? J. Sustain. Tour. 2019, 27, 74-96. [CrossRef]

57. Cheng, M.; MacKenzie, S.H.; Degarege, G.A. Airbnb impacts on host communities in a tourism destination: An exploratory study of stakeholder perspectives in Queenstown, New Zealand. J. Sustain. Tour. 2020, 1-19. [CrossRef]

58. Hof, A.; Blázquez-Salom, M. The Linkages between Real Estate Tourism and Urban Sprawl in Majorca (Balearic Islands, Spain). Land 2013, 2, 252-277. [CrossRef]

59. Cocola-Gant, A. Gentrificación turística. In Turistifación Global Perspectivas Críticas en Turismo; Cañada, E., Murray, I., Eds.; Icaria: Barcelona, Spain, 2019; pp. 291-308.

60. Gutiérrez, A.; Domènech, A. Understanding the spatiality of short-term rentals in Spain: Airbnb and the intensification of the commodification of housing. Geogr. Tidsskr. J. Geogr. 2020, 120, 98-113. [CrossRef]

61. Quattrone, G.; Proserpio, D.; Quercia, D.; Capra, L.; Musolesi, M. Who Benefits from the "Sharing" Economy of Airbnb? arXiv 2016, arXiv:1602.02238.

62. Liu, X.; Andris, C.; Huang, Z.; Rahimi, S. Inside 50,000 living rooms: An assessment of global residential ornamentation using transfer learning. EPJ Data Sci. 2019, 8, 4. [CrossRef]

63. Teubner, T. The web of host-guest connections on Airbnb: A network perspective. J. Syst. Inf. Technol. 2018, 20, 262-277. [CrossRef]

64. Farmaki, A.; Stergiou, D.; Kaniadakis, A. Self-perceptions of Airbnb hosts' responsibility: A moral identity perspective. J. Sustain. Tour. 2019, 1-21. [CrossRef]

65. Sequera, J. Gentrificación: Capitalismo Cool Turismo y Control del Espacio Urbano; Los libros de la Catarata: Madrid, Spain, 2020; 98p.

66. Jover, J.; Díaz-Parra, I. Who is the city for? Overtourism, lifestyle migration and social sustainability. Tour. Geogr. 2020, 1-24. [CrossRef]

67. García-Hernández, M.; De La Calle-Vaquero, M.; Yubero, C. Cultural Heritage and Urban Tourism: Historic City Centres under Pressure. Sustainability 2017, 9, 1346. [CrossRef]

68. Jover, J.; Berraquero, L. Habitantes o Visitantes. El impacto del alquiler vacacional en el mercado de vivienda en Sevilla. Ciudad y Territorio Estudios Territoriales 2020, LII, 717-734. [CrossRef]

69. Sequera, J.; Nofre, J. Touristification, transnational gentrification and urban change in Lisbon: The neighbourhood of Alfama. Urban Stud. 2020, 57, 3169-3189. [CrossRef]

70. Berlage, L.; Terweduwe, D. The classification of countries by cluster and by factor analysis. World Dev. 1988, 16, 1527-1545. [CrossRef]

71. Yu, M.; Cheng, M.; Yu, Z.; Tan, J.; Li, Z. Investigating Airbnb listings' amenities relative to hotels. Curr. Issues Tour. 2020, 1-18. [CrossRef]

72. Cheng, M.; Jin, X. What do Airbnb users care about? An analysis of online review comments. Int. J. Hosp. Manag. 2019, 76, 58-70. [CrossRef]

73. Singh, M.; Choudhury, S.K.; Banerjee, R.; Manniste, A. Airbnb New York City: Demystifying the Superhost Program. 2018, pp. 1-7. Available online: http://insideairbnb.com/get-the-data.html (accessed on 19 March 2020).

74. Tussyadiah, I.; Park, S. When guests trust hosts for their words: Host description and trust in sharing economy. Tour. Manag. 2018, 67, 261-272. [CrossRef]

75. Henry, D.B.; Dymnicki, A.B.; Mohatt, N.; Allen, J.; Kelly, J.G. Clustering Methods with Qualitative Data: A Mixed-Methods Approach for Prevention Research with Small Samples. Prev. Sci. 2015, 16, 1007-1016. [CrossRef] [PubMed]

76. Jurun, E.; Pivac, S. Cluster and multicriterial comparative regional analysis-Case study of croatian counties. Croat. Oper. Res. Rev. 2010, 1, 113-123. 
77. Martínez-Franzoni, J. Regímenes del Bienestar en América Latina; Fundación Carolina-Ce-ALCI: Madrid, Spain, 2007.

78. Paap, R.; Franses, P.H.; Van Dijk, D. Does Africa grow slower than Asia, Latin America and the Middle East? Evidence from a new data-based classification method. J. Dev. Econ. 2005, 77, 553-570. [CrossRef]

79. Sianes, A.; Ortega Carpio, M.L. Una Apuesta Global Por la Coherencia de Políticas Para el Desarrollo. Sí, Pero... ¿Qué Políticas? Rev. Econ. Mund. 2014, 36, 121-152.

80. Tezanos-Vázquez, S.; Quiñones-Montellano, A. ¿Países de renta media? Una taxonomía alternativa del desarrollo de América Latina y el Caribe * Middle income countries? An alternative development taxonomy of Latin America and the Caribbean ¿ Países de renta media? Una taxonomía alternativa del des. Revista Iberoamericana de Estudios de Desarrollo 2012, 1, 5-27.

81. Vázquez, S.T.; Sumner, A. Beyond Low and Middle Income Countries: What if There Were Five Clusters of Developing Countries? IDS Work. Pap. 2012, 2012, 1-40. [CrossRef]

82. Yan, L.; Wang, Y.; Ding, C.; Liu, M.; Yan, F.; Guo, K. Correlation Among Behavior, Personality, and Electroencephalography Revealed by a Simulated Driving Experiment. Front. Psychol. 2019, 10, 1524. [CrossRef]

83. Martín, J.M.M.; Mejía, K.A.Z.; Fernández, J.A.S. Effects of Vacation Rental Websites on the Concentration of Tourists-Potential Environmental Impacts. An Application to the Balearic Islands in Spain. Int. J. Environ. Res. Public Health 2018, 15, 347. [CrossRef] [PubMed]

84. E Silva, F.B.; Herrera, M.A.M.; Rosina, K.; Barranco, R.R.; Freire, S.; Schiavina, M. Analysing spatiotemporal patterns of tourism in Europe at high-resolution with conventional and big data sources. Tour. Manag. 2018, 68, 101-115. [CrossRef]

85. Harrison, D.; Sharpley, R. Mass Tourism in a Small World; CABI: Wallingford, Oxfordshire, UK, 2017; 262p.

86. Wang, D.; Nicolau, J.L. Price determinants of sharing economy based accommodation rental: A study of listings from 33 cities on Airbnb.com. Int. J. Hosp. Manag. 2017, 62, 120-131. [CrossRef]

87. Picornell, M. Insular identity an urban contexts: Representations of the local in the construction of an image of Palma. Isl. Stud. J. 2014, 9, 223-238.

88. Ward, J. Hierarchical groupings to optimize an objective function. J. Am. Stat. Assoc. 1963, 58, $236-244$. [CrossRef]

89. Aaker, D.A.; Day, S. Investigación de Mercados; McGraw-Hill: Ciudad de México, Mexico, 1989.

90. Aggarwall, C.C. (Ed.) Social Network Data Analytics; Springer: New York, NY, USA, 2011; 508p.

91. Kassambara, A. Practical Guide To Cluster Analysis in R; STHDA: New York, NY, USA, 2017; pp. 1-187.

92. Gan, G.; Ma, C.; Wu, J. Data Clustering: Theory, Algorithms, and Applications; Society for Industrial and Applied Mathematics: Philadelphia, PA, USA, 2007; 455p.

93. Charrad, M.; Ghazzali, N.; Boiteau, V.; Niknafs, A. Nbclust: An R package for determining the relevant number of clusters in a data set. J. Stat. Softw. 2014, 61, 1-36. [CrossRef]

94. Carslaw, D.C.; Ropkins, K. Openair-An R package for air quality data analysis. Environ. Model. Softw. 2012, 52-61. [CrossRef]

95. Wickham, H. ggplot2: Elegant Graphics for Data Analysis; Springer: New York, NY, USA, 2016; ISBN 978-3-319-24277-4.

96. Terkenli, T.S. Human Activity in Landscape Seasonality: The Case of Tourism in Crete. Landsc. Res. 2005, 30, 221-239. [CrossRef]

97. Andolina, C.; Signa, G.; Tomasello, A.; Mazzola, A.; Vizzini, S. Environmental effects of tourism and its seasonality on Mediterranean islands: The contribution of the Interreg MED BLUEISLANDS project to build up an approach towards sustainable tourism. Environ. Dev. Sustain. 2020, 1-12. [CrossRef]

98. Sáez-Fernández, F.J.; Jiménez-Hernández, I.; Rey, M.D.S.O. Seasonality and Efficiency of the Hotel Industry in the Balearic Islands: Implications for Economic and Environmental Sustainability. Sustainability 2020, 12, 3506. [CrossRef]

99. García-Ayllón, S. Urban Transformations as an Indicator of Unsustainability in the P2P Mass Tourism Phenomenon: The Airbnb Case in Spain through Three Case Studies. Sustainability 2018, 10, 2933. [CrossRef]

100. Cocola-Gant, A. Tourism gentrification. In Handbook of Gentrification Studies; Lees, L., Phillips, M., Eds.; Edward Elgar Publishing: Northampton, UK, 2018; pp. 281-293. [CrossRef]

101. Jover, J.; Díaz-Parra, I. Gentrification, transnational gentrification and touristification in Seville, Spain. Urban Stud. 2020, 57, 3044-3059. [CrossRef] 
102. Lerario, A.; Di Turi, S. Sustainable Urban Tourism: Reflections on the Need for Building-Related Indicators. Sustainability 2018, 10, 1981. [CrossRef]

103. Mao, X.; Meng, J.; Wang, Q. Modeling the effects of tourism and land regulation on land-use change in tourist regions: A case study of the Lijiang River Basin in Guilin, China. Land Use Policy 2014, 41, 368-377. [CrossRef]

104. Cocola-gant, A.; Muñoz, F.; Spilborghs, R.; Mansillla, J.A.; Pardo, D. Movimientos sociales y exclusión socioespacial en Barcelona. Pasos 2018, 12, 12.

105. Morales, S.; Garay, L.; Wilson, J. Airbnb's contribution to socio-spatial inequalities and geographies of resistance in Barcelona. Tour. Geogr. 2020, 1-24. [CrossRef]

106. Diaz-Parra, I.; Jover, J. Overtourism, place alienation and the right to the city: Insights from the historic centre of Seville, Spain. J. Sustain. Tour. 2021, 29, 158-175. [CrossRef]

107. Shabrina, Z.; Arcaute, E.; Batty, M. Airbnb's disruption of the housing structure in London. arXiv 2019, arXiv:1903.11205.

Publisher's Note: MDPI stays neutral with regard to jurisdictional claims in published maps and institutional affiliations.

(C) 2020 by the authors. Licensee MDPI, Basel, Switzerland. This article is an open access article distributed under the terms and conditions of the Creative Commons Attribution (CC BY) license (http://creativecommons.org/licenses/by/4.0/). 